\title{
Micro Enterprises and New Trends Towards their Development
}

\author{
PhD Arben Baushı1 \\ Prof. Dr. Vjollca Hasani² \\ Prof. Dr. Alba Dumi ${ }^{3}$ \\ ${ }^{1}$ Department of Math and Statistic" University of Vlore, Albania; Email: baushiarben@gmail.com \\ ${ }^{2}$ Dean of Economy Faculty, AAB Pristina University Kosovo; E-mail: v.hasani@gmail.com \\ 3 Dean of Graduated School, Management Department" Economy Faculty University of Vlore, Albania \\ Email: alba.besi12@gmail.com
}

Doi:10.5901/ajis.2015.v4n3s1p40

\section{Abstract}

SME treatment is a topic not widely applied in new Albanian economy. It is a new sector and consequently the basis on which rises are still fragile. In this treatment, what I want to tell and study has to do exactly with the importance of SME, their role in our economy and the importance of the future of SME. This sector is one of the sector of the economy which creates job vacancies, especially new jobs.Liquidity in these companies is too low, one of the characteristics of SME. The presence of SMEs in the market increases flexibility and promotes a specific information for small business needs. Thanks facilitating registration procedures and other factors that would refer to the following, there has been a marked increase in this sector in recent years. Strengthening the financial sector is the most important issue for the successful operation of small and medium enterprises (SME).

Keywords: Analyze of SME, Wald Statistic, Operations, Ratio Tests, SME investments, business plan.

\section{Introduction}

One of the issues currently plaguing the "world" of SME is their low financing depending on factors such as: the high level of interest, high collateral requirements and the lack of credibility on business plans. Finally, the pleasure it gave to me this topic to everyone who would like to transmit to everyone conveyed to pick up this topic.

Hypothesis: Economic development of a country like Albania depending on SME. Research question: Are SMEs one of the factors that directly affect the economic growth of a country? Does the development of the economy depend on a country's level of development, distribution, financing and encouraging SMEs?

\section{The Role of SME in Economy}

SMEconstitute the backbone of the economy. The SME sector has an important contribution to the process of economic development of a country. They are the engine of the economy, important source of employment and an important factor for industrial growth. They are a key factor in creating entrepreneurial spirit and innovation, thus making an important element of competitiveness and local economic development. For more SME sector in Albania accounts for about $80 \%$ of GDP, which is an important part of its total.

* Generating new jobs: SME contribute to the growth of employment in a larger scale than big business. Also in transition country, as well as Albania, SME in the long term could provide the bulk of employment.SME in Albania currently cover about $71 \%$ of the employees.( Albanian Progress report 2011)

* Flexibility: Flexibility has to do with changing activity of companies depending upon market conditions change and the quick adaptation to these changes. Small businesses are more inclined to be more flexible organizational forms. They can take on new workers when the demand for their products increases and to remove when demand falls down. This would be difficult for large businesses because of pressure from workers' organizations. (Albanian Progress report 2011)

* Presentation of various innovations: Small businesses are often very innovative company. They can submit new products, new management styles and new promotional strategies. A large part of the new products are 
created precisely by small businesses. On the other hand, a growing number of small businesses make economy and society more flexible. This can facilitate technological innovation, provide opportunities and new ideas, as well as enable the development of skills to implement these ideas.

* Stimulation of competition: Given that entry into the market for SME is relatively simple, due to the fact that the legal and administrative obstacles to the creation of a small business are very small, the number of enterprises operating in this sector recently has been increasingly growing. For this reason SME managers need to increase their skills and performance to meet the demands of customers better than competitors, in order to succeed in the market.

* Production of goods and efficient services: The transition from a centralized economy to a market economy was accompanied by large enterprises replacing former state-smaller enterprises and private firms. In this way significantly increases the number of owners, who represents a group of people with a commitment and greater accountability in the former centrally planned economies.

Considering that this group of persons are themselves the owners of the business units, this caused them to be more responsible and strive with all the means that you use the most efficient way possible own resources. This is because what do they benefit or fail of their business entity falls directly on them.Produces domestically (inner market), using mainly national sources.In this way it helps to technological developments and the development of professional skills within the country and in its regional development.

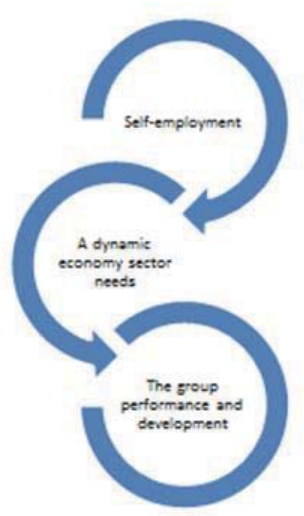

Graph 1: Flexibility to changes in demand and supply

* Self-employment can play a major role in the campaign to fight poverty, social exclusion and legitimizing informal sector activity.

* A dynamic economy sector needs a strong and independent medium business that offers stability, variety and performing sharing economic power, social and political one. So the absence of the element "medium" is a key issue for economic development.

\section{Literature Review and Hypotheses}

The approach via logistic regression is done to study the results of the students after the first semester according to the variables mentioned above. Results of the students are divided into two groups: less than 30 credits, which mean that they have not taken all the provided courses, and more than 30 credits, for those who have.

Studies on SMEs and economic growth, Raport of SME on economic growth

A number of studies have tried to explain SME and how they affect the economic growth. These studies mainly derived role of SME as an engine of economic growth but connected with perfection of the market and institutional role. While various skeptics question the efficiency of SMEs and their role speaking in favor of large firms (Biggs, 2002).

According to them, the growth of GDP per capita and the ratio of employment in manufacturing SME, show a strong positive correlation during the 1990's regressions applied clearly and detailed control to the opposite causal relationship and simultaneous bias or prejudice in the relationship between SME and growth. So the results do not 
necessarily lead to the conclusion that SME do not bring economic growth. In addition, they fail to reject the hypothesis certainly SME do not show a causal effect on the growth of GDP per capita.

\subsection{Research Goal}

Until now the business environment in Albania did not allow the private sector to lead the economic growth in the country. This is largely happens because law enforcement is not in act and weak economic infrastructure and social services and administrative inefficient bureaucratic barriers that do not allow to use competitive advantages and benefit from the free trade regime.

On the other hand, the lack of competitive advantage is the result of deficiencies in the process of learning the owner / manager. These deficiencies or gaps in knowledge, expertise and technical skills needed, generate a mismatch between current performance and desired performance or necessary for the firm in a competitive environment.

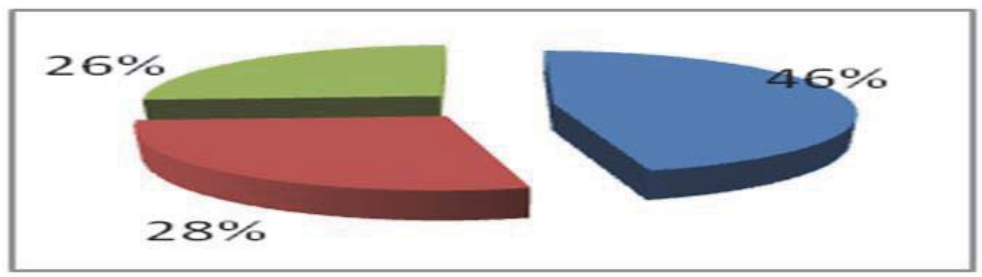

Graph 2: SME development and management capacity of economy grouth.

Too often, education and professional training of entrepreneurs in the past was not related to the business they started. The practice has been the best teacher for them. But today, when competition is strong and growing market opportunities are dwindling, often the experience of managers / owners of SME it is not sufficient to continue business growth.

This affects not only the growth opportunities in international markets but must take into consideration the fact that globalization brings international competition at the Albanian enterprises in their domestic markets.Various international reports, including the Progress Report by the European Commission note that the business environment for SME in Albania got good improvements, particularly with regard to the registration of companies and access to finance.

However, significant gaps remain in terms of human capital development and technological capacity, preventing Albanian companies' ability to compete properly with EU SMEs and thus survive the competition of the EU market.

It is known that technological developments in recent years have progressed by leaps galloping and small and medium enterprises in Albania are not of itself sufficient to qualify resources for adapting to these changes. This is reflected in the productivity and quality of products Albanian SMEs, compared with those of the EU leaves much to be desired.

Another factor worthy of mention is e-commerce.During recent years we have added internet users in Albania, especially the younger generation, but still can not speak of a massive use of internet among small and medium. Infrastructure generally is being considered very poor, limited use mainly in Tirana and much less in some of the major districts, while it is almost non-existent in other districts of the country.

\subsubsection{Financial barriers, legal and institutional}

Becket al. They have shown that higher barriers actually translated into slower growth. Financial barriers to small firms have almost twice the impact on annual growth have is these financial barriers to large businesses. This difference is even more powerful in the case of barriers related to corruption and the legal system, where small firms are "suffering" the consequences about three times more in terms of growth, than large businesses. So small businesses not only report higher barriers, but also these barriers affect more in the case of these businesses. 


\section{Source: EBRD (2012)}

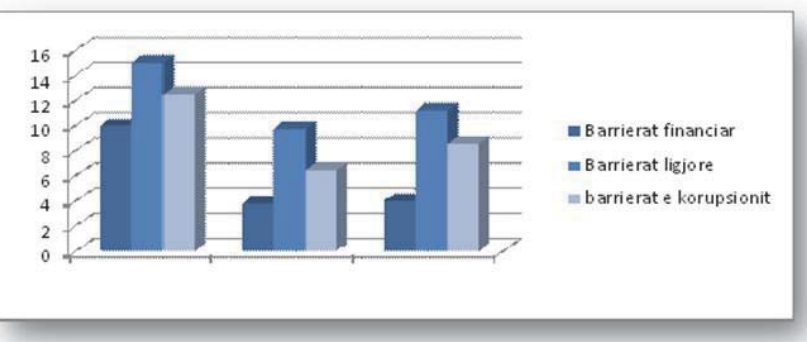

In general, institutional development is the most important characteristic in various countries that explains the differences between countries in terms of financial barriers. Firms in countries where higher institutional development report for lower financial barriers than firms in countries with lower institutional development. The positive effect of the financial and institutional development can be observed and in the use of external sources of funding.

\section{Sample and Data Collections}

The purpose of logistic regression is to correctly predict the outcome category for special occasions using logistic regression model. To achieve this goal, it has been created a model that includes all predictor variables that are useful to predict the outcome. (Ramosacaj, M, Hasani V, Dumi A

"Application of Logistic Regression in the Study of Students' Performance Level (Case Study of Vlora University)",Journal of Educational and Social Research, 2015

2. Test: The hypothesis arises if there are sufficient evidence in the sample to refuse the null hypothesis and therefore to accept the alternative one, that the coefficients are different from zero. Confidence intervals can be used for hypothesis testing and for regression coefficients as well.

There are a variety of reasons that explain the low level of lending to the private sector in Albania and in certain periods of time have operated with different intensity.

Macroeconomic instability.Despite the results achieved in this regard, we still have to do with unconsolidated structure ;

Monetary policy and banking regulation.For years, it is implementing a tight monetary policy trying to reduce inflation. It certainly has its negative side as far as restrict lending to the economy. While due to the high risk of surveillance rules are such that affected the credit (lending/loans) limit, eg demand for regulatory capital; limiting commercial banks that hold more than $20 \%$ of outstanding loans in time to make loans;

Regression equation form would be:

$\theta=\frac{\mathrm{e}^{\left(0.54-0.91 x_{1}-0.47 x_{5}+0.62 x_{6}-0.45 x_{7}\right)}}{1+\mathrm{e}^{\left(0.54-0.91 x_{1}-0.47 x_{5}+0.62 x_{6}-0.45 x_{7}\right)}}$

By applying the method of correlation analysis, we noted that there is not a significant correlation between the type of school and results of exams (around 0.02), as well as between other variables, which shows that it is less likely to have(collations) between independent variables.

\begin{tabular}{|c|c|c|c|}
\hline DATA & & DATA TYPE & VALUES \\
\hline & Dependent & Variable & \\
\hline Taken credits & $\begin{array}{l}\text { Passing } \\
\text { Failing }\end{array}$ & Binary & $\begin{array}{ll}0- & \text { Less than } 30 \text { credits } \\
\text { 1- } & \text { More than } 30 \text { credits }\end{array}$ \\
\hline & Independent & Variable & \\
\hline P1 Gender & Independent & Binary & $\begin{array}{ll}1- & F \\
0- & M\end{array}$ \\
\hline P2 Type of school & Independent & Binary & $\begin{array}{ll}0- & \text { Public } \\
1- & \text { private }\end{array}$ \\
\hline P5 High school points & Independent & Non- binary & $\begin{array}{ll}1- & 5000-4000 \\
2- & 4000-3000 \\
3- & 3000-2000\end{array}$ \\
\hline P4 Taken credits & Credits & Binary & $\begin{array}{ll}0- & \text { Less than } 30 \text { credits } \\
1- & \text { More than } 30 \text { credits }\end{array}$ \\
\hline
\end{tabular}




\begin{tabular}{|c|c|c|c|}
\hline P3 School location & Independent & Binary & $\begin{array}{ll}0- & \text { Village } \\
1- & \text { Urban area }\end{array}$ \\
\hline P6 Social environment & Independent & Non- binary & $\begin{array}{ll}1- & \text { stressful } \\
2- & \text { not stressful } \\
\text { 3- } & \text { very stressful }\end{array}$ \\
\hline
\end{tabular}

Source: (Ramosacaj, M, Hasani V, Dumi A "Application of Logistic Regression in the Study of Students' Performance Level (Case Study of Vlora University)",Journal of Educational and Social Research, 2015

Problems with property titles and registration. This has limited the opportunities for businesses to borrow because they could not offer sufficient guarantees to obtain a loan;

Informal economy, corruption, tax evasion,factors that reduce the reliability of businesses to obtain loans from banks, as reduce transparency;

The lack of tradition in bank-client relations.Albanian businesses, are generally young and as such does not create confidence for taking loans from banks;

\section{Conclusions}

On the basis of the theory of duality small businesses realize different activity than large businesses, small businesses avoid dealing directly with large businesses which means that there are great business competitors. BM are better at producing new technologies,basic ones while BV are best to transform them into new products to market.

Large businesses are more successful in large-scale activities, more efficient production and marketing of products, while on the other hand BV are specialized in (Nietzsche study)markets and in creating additional markets for the products at the end of their life cycle .

So, these theories are based on the fact that these two categories of businesses have different approaches in some limited production factor, this factor may be associated with entrepreneurial skills or ( the theory know-how) in any natural resource SB and SME are not always competitive, but these two businesses often operate and depend on each other.

SME in many cases sub-contract activities and supply intermediate goods to small businesses, so these can operate in many areas such as. SME can supply raw materials BM and intermediate products, also BM are the one that establishes conditions for the growth of industries in which SME are in greater numbers.

\section{Refernces}

Alenn\& Ruth Taplin, Risk Management and Innovation in Japan, Britain and the USA , Routledge, Milton Park, Abingdon, Oxon 2005, faqe 155;

Bobek Shuklev dhe Veland Ramadani, Biznesi i vogel dhe ndermarresia, UEJL, Tetove, 2013

Albanian Progress Report year 2011. Albanian Development and SME growth

Bluford H. Putnam, Richard M. Bookstaber, Robert M. McLaughlin, Andrew W. Lo, Desmond Mac Intyre, Ch, Risk ManagementPrinciples and Practices 1999;

Carl L. Pritchard, Risk Management- Concepts and Guidance, 2001;

Christopher L. Culp, The ART of Risk Management, 2002;

Dumi A The SME Advanced analyze, ISBN: 978/928/196231 pp 234,349,356

Dumi A The SME Advanced analyze, ISBN: 978/928/196231 pp 335,399,3405

K. H. Spencer Pickett, Auditing the Risk Management Process, John Wiley \& Sons, Inc., Hoboken, New Jersey 2005, faqe 2;

Matthew Leitch, Intelligent internal control and risk management, Published by Gower Publishing Limited, Hampshire, 2008

Michel Crouhy, Robert Mark, Dan Galai, Risk Management, McCraw-Hill, New York, 2000, faqe 622;

Moto Widow, S. J. ,"Orientation toward the job and organization", Effects of human resource systems on manufacturing performance and turnover, Academy of Management Journal, VOL. 37, Nr. 3.

Laursen K., Foss N. J., New human resource management practicescomplementarities and the impact on innovation performance, Cambridge Journal Of Economics, 27, 2003

Ramosacaj, M, Hasani V, Dumi A "Application of Logistic Regression in the Study of Students' Performance Level (Case Study of Vlora University)",Journal of Educational and Social Research, 2015

De Castri M., "Spazio e organizzazione: verso un nuovo rapporto"

Knittel-Ammerchuber, "Architecture: the element of success. Building strategies and business objectives", Becker and Steele, "Understanding Organizational Ecology. 